\title{
Effects of Innovativeness and Firm Resources on the Growth of Small Enterprises in the Ga South Municipality in Ghana
}

\author{
Nana Addae Ayepa \\ Centre for Entrepreneurship and Small Enterprise Development \\ University of Cape Coast, Cape Coast \\ Rosemond Boohene \\ (Corresponding author) \\ Centre for Entrepreneurship and Small Enterprise Development \\ University of Cape Coast, Cape Coast \\ Email: rboohene@ucc.edu.gh \\ Mavis Serwaa Benneh Mensah \\ Centre for Entrepreneurship and Small Enterprise Development \\ University of Cape Coast, Cape Coast \\ DOI//http://dx.doi.org/10.4314/gjds.v16i1.1
}

\begin{abstract}
This study sought to examine the effects of innovativeness and firm resources on the growth of small enterprises in the Ga South Municipality in Ghana. The study employed a quantitative approach using a cross sectional design. A sample of 188 registered small enterprises was selected from a population of 368 based on Krejcie and Morgan's 1970 Table for determining sample size. Simple random sampling technique was used in selecting the sample for the study. Data were collected using a self-administered questionnaire with a response rate of 55 percent. Key findings were that innovativeness and firm resources both affected the growth of small enterprises in the Ga South Municipality. It was concluded that to enhance their growth, small enterprises must be encouraged to be more innovative, reinforce and maximise the effective use of resources.
\end{abstract}

Keywords: Small Firms, Resources, Innovativeness, Growth, Ga South Municipality 


\section{INTRODUCTION}

Innovation has become a key tool for small enterprises which strive to cope with today's highly competitive environment (Ellonen, Blomqvist \& Puumalainen, 2008; Liu \& Phillips, 2011). According to Schumpeter (1934), Scherer (1986) and Keklik (2018) innovativeness captures the idea of applying creativity in the technical, marketing and organizational functions of a firm in order to develop new goods and services for the purposes of wealth creation. Similarly, firm resources have become a basis for firms which aim at gaining competitive advantage. That is, the goal of performing better than their competitors in the same industry (Barney, 2001; Kraaijenbrink, Spender \& Groen, 2010). As noted by O’Regan and Ghobadian (2004), firm resources provide the stock of knowledge, physical assets, human capital, and other tangible and intangible factors that enable small firms to obtain a competitive advantage.

The importance of innovativeness and the resources of firms to their growth, is widely acknowledged and established in literature. Zahra and Covin (1995) argue that with sufficient resources, firms are able to experiment new things, which do not only increase their innovative potential, but also enable the enterprises to grow. In addition, Wiklund, Patzelt and Shepherd (2007) emphasised that, to achieve growth, small enterprises must go beyond innovativeness to develop valuable firm resources. The observations are made upon the premise that small enterprises grow through the introduction of new and better goods and services, implementation of new knowledge, methodologies and technologies, and improvement on their resources (Chirico \& Salvato, 2008).

In relation to the above-mentioned assertions, studies, such as those conducted by Alpay, Bodur, Yilmaz and Buyukbalci (2012) in Turkey, Salavou and Avlonitis (2008) in Greece and Ngugi, McOrege and Muiru (2013) in Kenya confirm the importance of innovativeness and firm resources to firm growth. Nevertheless, a comparative study between the United Kindgom by Storey, Boso and Kadogan (2015) showed that whereas in Ghana access to finance enhanced the relationship between product innovativeness and new product performance, such a relationship was not observed in the United Kingdom. The authors attributed this finding to the unique institutional environments of the two countries.

In Ghana, small enterprises provide over 80 percent of the total employment (Abor \& Quartey, 2010). According to Adjei (2012), statistics from the Registrar General's Department suggest that 92 percent of companies registered are micro, small and medium-sized enterprises (MSMEs). However, despite the role played by these enterprises, studies on innovativeness and firm resources are few with 
majority focusing on managerial skills and financial resources (Abor \& Quartey 2010). The bulk of studies conducted on small enterprises were mainly carried out amongst small manufacturing enterprises in the European, North American and, more recently, Asian economies (Robson \& Obeng, 2008; Woldie, Lieghton, \& Adesua, 2008; Yan, 2010). Thus, the situation pertaining to small enterprises in the manufacturing sector and in a developing country context is unclear. Besides, out of the numerous literature focusing on the impact of small enterprises on economies as well as challenges facing SMEs in Ghana (Abor \& Quartey, 2010), few have delved into the effect of innovativeness and firm resources on the growth of small enterprises. This appeared to be a serious omission, because small enterprises are major employers in the economy and provide vital contribution to the economic growth of Ghana (Hayford, 2012; Mensah, 2004).

The study was conducted in the Ga South Municipality, one of the sixteen administrative districts of the Greater Accra Region of Ghana. The Ga South Municipality was carved out of the Ga West Municipality in November 2007 and was established by Legislative Instrument 2134 in July 2012 with Weija being the Municipal capital. Ga South Municipality was chosen for the study because economic activities in the Municipality vary from petty trading to a few established firms with most employees as service and sales workers, craftsmen and trade workers (Ghana Statistical Service, 2012a). Thus, small enterprises form the predominant structure of the local economy (Ghana Statistical Service, 2012b).

Very few works have been conducted on small enterprises in the Municipality. With respect to the effect of innovativeness and firm resources on the growth of small enterprises, the study emerges as the first to be conducted in the region. The objectives of this research, therefore, were to assess the effect of innovativeness on firm resources; examine the effect of innovativeness on the growth of small enterprises; ascertain the effect of firm resources on firm growth; and examine the moderating effect of firm resources on the innovativeness - growth relationships of small firms in the Ga South Municipality in Ghana.

The paper is organised into five sections. The next section examines the theoretical framework for the study. This is followed by the methodology, and results and discussions. The fifth section focuses on the conclusions and implications, limitations and suggestions for future research.

\section{THEORETICAL FRAMEWORK}

The resource-based view (RBV), one of the theories used in explaining the importance of resources to a firm (Barney, 1991; Schumpeter, 1934), underpins 
the study. RBV explains firm resources and innovativeness as the major drivers of competitive advantage, resulting in economic growth.

\section{Resource-Based View}

The resource-based theory highlights the role of a firm's internal characteristics and its environment in determining growth (Bruderl, Preisendorfer, \& Ziegler, 1992). It postulates that sustained and continual competitive advantage results from strategically combining a firm's heterogeneous resources, including distinctive capabilities, knowledge, skills and processes (Robson, Haugh \& Obeng, 2009). In general terms, Resource-Based View (RBV) regards a firm as a composition of heterogeneous resources and explains the growth differences among firms, in relation to internal or firm-level factors and the effects of innovativeness as a firmspecific resource on firm growth (Barney, Ketchen, \& Wright, 2011; Schumpeter, 1934). According to Chiang and Yan (2011), the foundation of RBV makes it globally accepted that firm growth, competitive advantage and sustainability are associated with identifiable sets of productive resources and capabilities.

The theory relies on two main assumptions. Firstly, it is assumed that firms achieve competitive advantage by using their different bundles of resources. Secondly, it is assumed that resources that are difficult to obtain by competitors, because of the exorbitant cost of developing, acquiring or using them, also create a competitive advantage (Mata, Fuerst, \& Barney, 1995). However, the theory has been criticised for vagueness of terminology, and the lack of commonality of terms (Foss, 1998; Rugman \& Verbeke, 2002; Williamson, 1999). Moreover, the RBV researchers also challenge the foundation of the theory, suggesting that the view appears to assume what it seeks to explain (Hoopes, Madsen \& Walker, 2003). In spite of these criticisms, the theory has heightened knowledge regarding the nature, characteristics and potential usage of resources in unique ways (Iakovleva, 2004; Irava \& Moores, 2010).

Secondly, as noted by Grigoriou and Rothaermel (2014), RBV is needed to explain innovativeness as a vehicle of firm growth and a potential source of firm-level performance heterogeneity. To this study, RBV has contributed immensely to innovativeness, knowledge on the application of resources, the sustainability of competitive advantage and effect on firm growth (Barney, 2001; Kraaijenbrink et al., 2010). Moreover, RBV served as the foundation and also help explain how innovativeness and firm resources create sustained competitive advantage which subsequently leads to sustained performance of small firms (Robson et al., 2009). 


\section{Innovativeness and Small Firm Growth}

Innovativeness is paramount to the survival and growth of small enterprises. A study by Rosenbusch et al. (2011) identified that innovativeness has strong positive effect on financial growth measures such as return on sales, returns on assets and profitability. Moreover, Rosli and Sidek (2013) recorded a strong positive relationship between innovativeness and non-financial performance measures. Ngugi, McOrege and Muiru (2013) examined the influence of innovativeness on the growth of small and medium-sized enterprises. They based their research on the RBV and operationalised innovativeness to include new goods and services, new processes and technological advancement, while enterprise growth was operationalised as sales growth, employment growth, profit, market share growth, customer satisfaction and owner's/manager's satisfaction. They found that both the individual and composite dimensions of innovativeness had significant positive relationships with growth of SMEs in Kenya. Salavou and Avlonitis (2008), similarly, investigated the influence of product innovativeness on the performance of small and medium-sized manufacturing, food and beverages, and textile enterprises in Greece and concluded that product innovativeness influenced performance. In another related study, Alpay, Bodur, Yilmaz and Buyukbalci (2012) examined the innovativeness-SME growth relationship. The results indicated that there was a strong linear relationship between innovativeness and performance of SMEs in Turkey.

\section{Firm Resources and Small Enterprise Growth}

For new ventures, resources are significant for survival and growth (Barney, 1991). The strategic management literature indicates that firms' competitive advantages are the result of possessing internal resources, which their competitors lack (Peteraf, 1993; Teece, 2007). The existence of a positive relationship between firm resources and growth of small enterprise is well documented in literature (Gadenne \& Sharma, 2009). Vicente, Abrantes, Seabra and Teixeira (2015) investigated the influence of firm resources on firm growth. Using the RBV theory, the study intended to understand how a set of three innovation resources and capabilities influence dynamic capabilities and performance in export markets. The study found that innovativeness, technological capabilities and innovation strategy have a positive and direct impact on dynamic capabilities. They found that dynamic capabilities influence positively export firms' market performance.

Rasmussen (2014) examined the firm resources-SME growth relationship by analysing the effect of internal resources as drivers of high growth of 345 gazelle and 135 non-gazelle SMEs in Norway. They discovered that the high-growth SMEs 
scored higher on innovativeness, learning, and creative climate. This observation lends support to the notion that there is no single indicator that determines growth. Also, Bakar and Ahmad (2010) sought to answer which of a firm's resources contributes most to performance. Their findings indicated that, in Malaysia, intangible resources are the main drivers of performance. In addition, tangible resources have a significant positive relationship with performance in Malaysian SMEs.

\section{Innovativeness, Firm Resources and Small Enterprise Growth}

Research has identified that innovativeness enhances the influence of firm resources on small enterprises' growth (Chiang \& Yan, 2011; Kraaijenbrink et al., 2010; Wiklund et al. 2007). Bakar and Ahmad (2010), for example, asserted that without adequate intangible resources, all intentions of a firm, referred to as its innovativeness and plans, are bound to fail. Price, Stoica and Boncella (2013) using a sample 430 SMEs in Australia and USA found during their study that firm resources had a statistically significant influence on innovativeness. They also, argued that firm resources and innovativeness significantly enhanced each other's influence on SME performance. Price et al. (2013) examined the relationship between innovativeness, firm resources, and SME performance. The study employed resource-based view theory to ascertain the influence of innovativeness and firm resources on the performance of SMEs in Australia and USA. Their findings revealed that firm resources had a statistically significant influence on innovativeness. The study found that firm resources and innovativeness significantly enhanced each other's influence on SME performance.

Additionally, a study by Sonja and Ljiljana (2012) investigated the relationship between innovativeness, firm resources and SME growth. They defined innovativeness as a new or significantly improved good or service. Their findings revealed that SMEs with weak resources and capabilities contribute to occurrence of development problems. Secondly, the presence of financial constraints is a significant predictor of development problems. Also, collaborating resources have significant positive effect on probability of innovation despite development problems, and both marketing and organizational innovations improve the growth of firms despite development problems. Likewise, Marcati et al. (2008) examined the role of SME entrepreneurs' innovativeness and personality in the adoption of innovations to yield growth. The findings showed that entrepreneurs' innovativeness and personality significantly influenced the adoption to innovations and had a corresponding effect on SME growth. 


\section{METHODOLOGY}

The quantitative research approach was adopted for this study, since the main thrust of the study was to test the relationships among innovation, firm resources and small firm growth (Creswell \& Plano Clark, 2007; Terrell, 2012). Thus, from the discussions in the previous sections on the RBV and review of related literature, the following null and alternative hypotheses were developed to be tested:

Ho: Innovativeness does not positively affect firm resources of small enterprises in the Ga South Municipality.

H1: Innovativeness positively affects firm resources of small enterprises in the Ga South Municipality.

Ho: Innovativeness does not positively affect growth of small enterprises in the Ga South Municipality.

H1: Innovativeness positively affects growth of small enterprises in the Ga South Municipality.

Ho: Firm resources does not positively affect growth of small enterprises in the Ga South Municipality.

H1: Firm resources positively affect growth of small enterprises in the Ga South Municipality.

Ho: Firm resources does not moderate the relationship between innovativeness and small enterprise growth in the Ga South Municipality.

H1: Firm resources moderate the relationship between innovativeness and small enterprise growth in the Ga South Municipality.

This research also employed cross-sectional design for three reasons. Firstly, the aim was to determine comparison, and relationship between the dependent variable and the two independent variables and to overcome the shortcomings of exploratory and descriptive research designs (Sekaran \& Bougie, 2010). Secondly, in the view of Tabachnick and Fidell (2007), because the data was collected at one point in time, cross-sectional design is most suitable. The cross-sectional design was adopted in order to test hypotheses, and reasonably help in the generalization of the study (Rasmussen, 2014; Saunders, Lewis \& Thornhill, 2012).

A questionnaire was designed based on the literature review and the empirical context as well as theoretical and managerial considerations. The questionnaire contained items on demographic characteristics, innovativeness, firm resources and growth as well as close-and open-ended questions. The study adopted the questionnaire used in the research of Alpay et al. (2012), Edelman, Brush and Manolova (2005), OECD (2005) and Rasmussen (2014) on innovativeness, 
firm resources and small enterprise growth. The questionnaire was made up of five sections. In addition, with the exception of the demographic and firm characteristics, a seven-point Likert scale of ' 1 ' to ' 7 ' with ' 1 ' indicating least agreement and ' 7 ', highest agreement, was employed for the variables innovativeness, firm resources and growth.

Innovativeness was measured using a four-dimensional construct: product innovativeness, process innovativeness, market innovativeness and organizational innovativeness, generated from previous research, particularly studies by Alpay et al. (2012) and OECD (2005). Firm resources were also operationalised based on studies by Edelman et al. (2005) and Rasmussen (2014). The ten-item resource list comprised financial resources, skilled, quality customer services, well-trained and professional employees, uniqueness of service, good sanitation, and possession of reputational resources. SME growth was measured utilising both financial and non-financial measures (Tangen, 2003). Thus, increased customer satisfaction, new goods or services, increased profit margin, increased revenue, ability to create jobs, ability to self-finance expansion, growth in employment and lower cost of operation were adapted from studies by Alpay et al. (2012), Boermans and Roelfsema (2015), Price et al. (2013) and Rasmussen (2014).

The population comprised all small enterprises in the manufacturing sector in the Ga South Municipality that were registered with the National Board for Small Scale Industries (NBSSI) as of October 2015. Data of all small enterprises were secured from NBSSI Clients' Database. The database comprised a total of 368 small enterprises. A sample size of 188 was determined using Kejcie and Morgan's 1970 table and selected through simple random sampling. The lottery method was employed to select specific small enterprises included in each sampled category.

According to Pallant (2010), pre-test is a test required ahead of a main survey to know the effectiveness of randomization. As a result, pre-test of 45 small enterprises operating in food processing, handicraft, soap and detergents, wood processing, clothing and textiles, and mechanics located within the Ga Central Municipality in Ghana were determined and selected through lottery method and random numbers method. After all the necessary changes were effected, the questionnaire was then hand delivered to the respondents. At the end of the agreed two-week period, 103 respondents representing 55 percent had successfully completed the questionnaires. The questionnaires were filled by key decision makers, managers or owner-managers, depending on who was in charge of the SME.

Data collected were analysed quantitatively using both descriptive and inferential statistics. Data were transferred into computer files and analysed using Statistical 
Product and Service Solutions (SPSS version 16.0). To test the hypotheses, using regression analysis, a preliminary analysis was carried out on the data to determine its suitability for the analysis that was performed. As recommended by Tabachnick and Fidell (2007) and Pallant (2010), the significant values of the KolmogorovSmirnov statistic, the histogram and normal probability plots, labeled 'Normal Q-Q Plot,' were relied upon in determining normality or otherwise of the distribution. Significant values greater than .05, a bell-shaped histogram and a reasonably straight normal probability plot, indicated normal distribution. The respective histograms and probability plots for all three variables were normally distributed.

The study used the standard multiple regression technique, adopted from Leech, Barrett and Morgan (2005), in testing hypothesis one for two major reasons. According to Leech et al. (2005), standard multiple regression technique permits the concurrent entry of different predictor variables into a model, enabling the base analyses, findings and conclusions on a single scenario. Moreover, Pallant (2010) explained that the results generated by this technique indicate the separate contribution of each predictor variable to the total variance in a dependent variable. The assessment was based on the beta $(\beta)$ values, partial correlation values ( $r$ ), coefficient of determination $\left(\mathrm{R}^{2}\right)$, and the corresponding significance levels ( $\mathrm{p}$-values). As suggested by Pallant (2010), partial correlation values ( $r$ ) were interpreted according to Cohen's (1988) guidelines such as small/weak $(r=.10-.29)$, medium ( $r$ $=.30-.49)$ and large/strong $(r=.50-1.0)$.

\section{RESULTS AND DISCUSSION}

This section discusses the background information of small enterprises surveyed as well as the demographic characteristics of respondents. It proceeds with a discussion of the relationships between innovativeness and firm resources as well as their effects on SME growth. As indicated earlier, the analyses were carried out using descriptive and multiple regression.

\section{Background Characteristics}

A preliminary analysis was carried out on the data using descriptive statistics. The results indicate that $56.1 \%$ were sole proprietorships, whilst private companies and partnerships formed $42.7 \%$ and $1.20 \%$ of the sample respectively. There was no public company. From the findings, it appears that the preference for sole proprietorships, as a legal form of ownership, resulted from the low start-up costs, the minimal legal procedures required for such establishments, and the desire to exercise full control and avoid ownership and profit-sharing conflicts. Regarding the staff strength of the enterprises, the mean number of full-time employees per enterprise was 12.25 
with the minimum and maximum numbers being 1 and 44 respectively. Whereas $54.4 \%$ of the small enterprises employed fewer than 10 full time workers, $8.2 \%$ employed more than 30 workers. Almost 26.9\% of small enterprises surveyed did not have part-time employees, while the remaining $73 \%$ employed persons on parttime basis. The mean number of part-time employees was 2.56. This shows that the small enterprises surveyed in the Ga South Municipality have more full-time employees than part-time employees.

Moreover, $50.30 \%$ of the respondents were females, whilst males were $49.7 \%$. These results provide an interesting contrast to the Global Entrepreneurship Monitor (2010), which reports a greater involvement in entrepreneurship among males than females in most developed and developing economies. The mean age of respondents was 37.61 years with the youngest and oldest being 21 and 59 years respectively. Nevertheless, $14.04 \%$ of the respondents were below the age of 30 , whereas $37.43 \%$ were 40 years and above.

\section{Innovativeness and Firm Resources}

The first objective and hypothesis sought to examine the effect of innovativeness on firm resources of small enterprises in the Ga South Municipality in Ghana. Table 1 shows how innovativeness influences firm resources.

Table 1: Standard multiple regression analysis summary for firm age, ownership form, innovativeness predicting firm resources

\begin{tabular}{|l|l|l|l|l|l|l|}
\hline Variable & Beta $(\beta)$ & t-stats & P - value & r & $\mathrm{R}^{2}$ & ${\text { Adj } \mathrm{R}^{2}}$ \\
\hline Constant & 2.869 & 0.005 & & & & \\
\hline Firm age & 0.069 & 1.156 & 0.249 & 0.332 & 0.110 & 0.105 \\
\hline Ownership form & 0.008 & 0.144 & 0.886 & 0.190 & 0.036 & 0.030 \\
\hline Innovativeness & 0.692 & 11.907 & $<0.001$ & 0.720 & 0.518 & \\
\hline
\end{tabular}

$\mathrm{R}^{2}=.523 ; \mathrm{F}(3,167)=60.964, \mathrm{p}<0.001$

Adjusted $\mathrm{R}^{2}=.514 ; \mathrm{F}(3,167)=60.964, \mathrm{p}<0.001$

From the table above, it can be inferred that innovativeness explained unique variance in firm resources $\left(\mathrm{R}^{2}=.523\right.$; Sig. < 0.001). Thus, $52.3 \%$ of any adjustment in firm resources was attributed exclusively to an adjustment in innovativeness. The total variance figure was $\mathrm{R}^{2}=.523$ (Sig. < 0.001). As shown in Table 1 above, the significant value for the total variance figure is less than 0.05. The study therefore, rejects the null hypothesis and accepts the alternative hypothesis that innovativeness positively affects firm resources of small enterprises in the Ga South Municipality with the implication that an upward effect in the level of 
innovativeness will result in a 52.3 percent variance in the level of firm resources. Innovativeness thus, results in a significant improvement in firm resources This confirmed the findings of studies by Price et al. (2013) and Wiklund et al. (2007) that innovativeness affects firm resources.

\section{Innovativeness and Small Firm Growth}

The second objective examined the effect of innovativeness on the growth of small enterprises in the Ga South Municipality in Ghana. A standard multiple regression technique was employed due to its ability to permit simultaneous entry of multiple variables and explain their individual influences on a single dependent variable (Pallant, 2010). The influence of firm age and ownership form were controlled in the model, which comprised innovativeness as predictor variable and small enterprise growth as the dependent variable. The total variance was $\mathrm{R}^{2}=.466$ ( Sig. <.ooo). This implies that innovativeness significantly affected the growth of small enterprise in the Ga South Municipality in Ghana thereby rejecting the null hypothesis and accepting the alternative hypothesis. Thus the alternate hypothesis which proffered a positive relationship between innovativeness and SME growth was supported. The finding confirmed studies by Ngugi et al. (2013) and Price et al. (2013) that innovativeness positively influenced small enterprise growth.

Table 2: Standard multiple regression analysis summary for firm age, ownership form, innovativeness predicting small enterprise growth

\begin{tabular}{|l|l|l|l|l|l|l|}
\hline Variable & Beta $(\beta)$ & t-stats & P-value & $\mathbf{r}$ & $\mathbf{R}^{2}$ & Adj $^{2}$ \\
\hline Constant & 3.088 & 0.002 & & & & \\
\hline Firm age & 0.074 & 1.130 & 0.260 & 0.320 & 0.102 & 0.097 \\
\hline Ownership form & 0.040 & 0.652 & 0.515 & 0.207 & 0.043 & 0.037 \\
\hline Innovativeness & 0.618 & 9.801 & $<0.001$ & 0.655 & 0.429 & \\
\hline
\end{tabular}

$\mathrm{R}^{2}=.437 ; \mathrm{F}(3,167)=43.248, \mathrm{p}<0.001$

Adjusted $\mathrm{R}^{2}=.427 ; \mathrm{F}(3,167)=43.248, \mathrm{p}<0.001$

\section{Firm Resources and Small Firm growth}

The third objective ascertained the effect of firm resources on small firm growth. Table 3 shows the results of the regression analysis. As evident from the results of the total variance in Table $3\left(\mathrm{R}^{2}=.501\right.$; Sig. <.000), the significant value is less than 0.05 . The study rejects the null hypothesis and accepts the alternative hypothesis that superior firm resources improve growth of small enterprises. That is, the implementation of a new or significantly improved good or service, process, marketing method, or organisational method in small enterprises enhanced firm 
growth. The finding buttresses those by Bakar and Ahmad (2010), Rasmussen (2014), and Robson et al. (2009) that the availability of firm resources is essential to the growth of small enterprises.

Table 3: Standard multiple regression analysis summary for firm age, ownership form, firm resources predicting small enterprise growth

\begin{tabular}{|l|l|l|l|l|l|l|}
\hline Variable & Beta $(\beta)$ & t-stats & P - value & $\mathbf{r}$ & $\mathbf{R}^{2}$ & Adj $^{2}$ \\
\hline Constant & 4.731 & $<0.001$ & & & & \\
\hline Firm age & 0.082 & 1.346 & 0.180 & 0.320 & 0.102 & 0.097 \\
\hline Ownership form & 0.054 & 0.923 & 0.357 & 0.207 & 0.043 & 0.037 \\
\hline Firm Resources & 0.663 & 11.390 & $<0.001$ & 0.661 & 0.437 & \\
\hline
\end{tabular}

$R^{2}=0.501 ; F(3,167)=55.908, p<0.001$

Adjusted $\mathrm{R}^{2}=0.427 ; \mathrm{F}(3,167)=55.908, \mathrm{p}<0.001$

\section{Innovativeness, Firm Resources and Small Firm Growth}

The fourth objective sought to examine the moderating effect of firm resources on the innovativeness-growth relationships of small enterprises in the Ga South Municipality in Ghana. With reference to Alpay et al. (2012) and Price et al. (2013), the hierarchical multiple regression technique was utilised to eliminate the effects of firm age and ownership form as control variables. The initial model, as shown in Table 4, revealed that 10.5 percent of the variance in small enterprise growth was caused by the controlled variables $\left(\mathrm{R}^{2}=.114\right.$; Sig. <.00o). From Table 5, after entering innovativeness in the model, the total variance in small enterprise growth rose to 43.7 percent $\left(\mathrm{R}^{2}=.437\right.$; Sig. < .000), indicating a 32.4 percent increase. In Table 4, the 32.4 percent variance attributable to innovativeness was lower as compared to the overall $\mathrm{R}^{2}$. This reduction justified the exercise in this step to control for firm age and ownership form in determining the actual effect of innovativeness on small enterprise growth (Anderson \& Eshima, 2011; Price et al. 2013). 
Table 4: Hierarchical multiple regression analysis summary for firm age, ownership form and innovativeness predicting small enterprise growth

\begin{tabular}{|l|l|l|l|l|l|l|}
\hline Variable & Beta & t-stats & Sig & $\mathrm{R}^{2}$ & Adj. $\mathbf{R}^{2}$ & $\mathrm{R}^{2}$ Change \\
\hline Model 1 & & & & 0.114 & 0.103 & 0.114 \\
\hline Firm age & 0.282 & 3.660 & 0.000 & & & \\
\hline Ownership Form & 0.113 & 1.465 & 0.145 & & & \\
\hline Constant & & 44.210 & 0.000 & & & \\
\hline Model 2 & & & & 0.437 & 0.427 & 0.324 \\
\hline Firm age & 0.074 & 1.130 & 0.260 & & & \\
\hline Ownership Form & 0.040 & 0.652 & 0.515 & & & \\
\hline Innovativeness & 0.618 & 9.801 & 0.000 & 0.324 & & \\
\hline Constant & & 3.088 & 0.002 & & & \\
\hline
\end{tabular}

Model 1: $\mathrm{R}^{2}=.114(2,168)=10.755, \mathrm{p}<0.01$

Adjusted $\mathrm{R}^{2}=0.103(2,168)=10.755, \mathrm{p}<0.01$

Model 2: $\mathrm{R}^{2}=.437(1,167)=96.063, \mathrm{p}<0.01$

Adjusted $\mathrm{R}^{2}=0.427(1,167)=96.063, \mathrm{p}<0.01$

Step three sought to examine the ability of innovativeness to affect firm growth after eliminating the effect of firm resources. The analysis involved the testing of hypothesis four that firm resources affect innovativeness-growth relationship (Table 5). 
Table 5: Hierarchical multiple regression analysis summary for firm age, ownership form, firm resources and innovativeness predicting small enterprise growth

\begin{tabular}{|l|l|l|l|l|l|l|}
\hline Variable & Beta & t-stats & Sig & $\mathrm{R}^{2}$ & Adj. $\mathrm{R}^{2}$ & $\mathrm{R}^{2}$ Change \\
\hline Model 1 & & & & 0.114 & 0.103 & 0.114 \\
\hline Constant & & 44.210 & $<0.001$ & & & \\
\hline Firm age & 0.282 & 3.660 & $<0.001$ & & & \\
\hline Ownership Form & 0.113 & 1.465 & 0.145 & & & \\
\hline Model 2 & & & & 0.501 & 0.492 & 0.388 \\
\hline Constant & 4.731 & $<0.001$ & & & & \\
\hline Firm age & 0.082 & 1.346 & 0.180 & & & \\
\hline Ownership Form & 0.054 & 0.923 & 0.357 & & & \\
\hline Firm Resources & 0.663 & 11.390 & $<0.001$ & 0.388 & & \\
\hline Model 3 & & & & 0.541 & 0.530 & 0.040 \\
\hline Constant & & 2.000 & 0.047 & & & \\
\hline Firm age & 0.041 & 0.697 & 0.487 & & & \\
\hline Ownership Form & 0.037 & 0.652 & 0.516 & & & \\
\hline Firm Resources & 0.466 & 6.130 & $<0.001$ & & & \\
\hline Innovativeness & 0.296 & 3.805 & $<0.001$ & 0.040 & & \\
\hline
\end{tabular}

Model 1: $\mathrm{R}^{2}=.114(2,168)=10.755, \mathrm{p}<0.01$

Adjusted $\mathrm{R}^{2}=.103(2,168)=10.755, \mathrm{p}<0.01$

Model 2: $\mathrm{R}^{2}=.501(1,167)=129.730, \mathrm{p}<0.01$

Adjusted $R^{2}=.492(1,167)=129.730, p<0.01$

Model 3: $\mathrm{R}^{2}=.541(1,166)=14.475, \mathrm{p}<0.01$

Adjusted $\mathrm{R}^{2}=.530(1,166)=14.475, \mathrm{p}<0.01$

After entering innovativeness in the model in Table 5 , the total variance rose from 50.1 to 54.1 percent, signifying a 4 percent increase in growth, attributable to innovativeness. Moreover, compared to the 32.4 percent variance obtained in step two in Table 4, the effect of innovativeness on growth was much lower. From the total variance figure $\left(\mathrm{R}^{2}=.541\right.$; Sig. < .001) the significant value is less than 0.05 ; the study therefore rejects the null hypothesis and accepts the alternative hypothesis that firm resources moderate the innovativeness-growth relationship.

The findings show that even highly innovative small enterprises still relied on firm resources to ensure successful implementation of plans to enhance growth and survival. The effect of innovativeness on small enterprise growth is largely enhanced by the amount of resources the firm controls. Thus, firm resources enhance small enterprises' ability to implement new goods and services, new ways and methodologies and achieve growth. Being innovative enhanced a firm's 
ability to effectively and efficiently deploy resources in the successful pursuit of opportunities. Without resources, therefore, entrepreneurs are absolutely helpless in their attempt to succeed. This finding buttressed Bakar and Ahmad (2010), Rasmussen (2014) and Vicente et al.'s (2015) studies that the innovativeness-growth relationship is stronger for well-resourced small enterprises.

\section{CONCLUSIONS AND IMPLICATIONS}

This paper sought to examine the effects of innovativeness, and firm resources on the growth of small enterprises in the Ga South Municipality. Significant relationships were found to exist among innovativeness, firm resources and small enterprise growth in the Municipality. Based on the findings, SME's are encouraged to pursue growth by being more innovative in terms of their operations, processes and organizational capacities. They are also entreated to speed up implementation of new marketing methods involving significant changes in product design, product placement, and promotion. SMEs are advised to invest in skilled and well-trained professional employees and offer quality customer service, as all these enhance SMEs growth. Furthermore, they need to strengthen their financial base and improve upon networks with relevant external advisors for vital information and other benefits to ensure increased growth. SMEs need to maximise the effective use of resources to enhance SME growth.

The study contributes to the understanding of the effects of innovativeness and firm resources on the growth of small enterprises utilising the resource-based view. It also complements the growing body of literature on small enterprise growth in general, but more particularly to the literature on innovativeness and firm resources in manufacturing enterprises. Despite the contributions of this research enumerated above there are a number of limitations that needs to be pointed out.

Firstly, the restriction of this study's population to small and medium-sized enterprises registered, with the National Board for Small Scale Industries in the Ga South Municipality for the year 2015, renders the findings, conclusions and recommendations applicable mainly to this group of SMEs. The choice of multiple regression tools for a model with a limited number of dependent variable informs suggestions for further studies. The reliance on key decision makers as the sole respondents raises questions bordering on possible bias, particularly with the assessment of SME growth.

This research provides an opportunity for several other researches to be conducted. It is suggested that further research be carried out to examine the reciprocal influence of SME growth on innovativeness and firm resources. Secondly, the 
relationships among the dimensions of innovativeness and firm resources should be examined. This will provide in-depth clarification vis-à-vis the influence of the components of both variables in enhancing growth. Thirdly, a study covering different categories of SMEs will present a more holistic picture of the effects of innovativeness and firm resources on growth. To conclude, a replication of this study on a longitudinal basis will reveal trends in the behaviour of the variables and enhance the quality of recommendations made to SMEs.

\section{References}

Abor, J. and Quartey, P. (2010). Issues in SME development in Ghana and South Africa. International Research Journal of France and Economics, 39, pp. 218-242.

Adjei, D.S. (2012). Micro, small and medium scale enterprise in Ghana: Challenges and prospects. A case study of Sekondi-Takoradi Metropolis. Unpublished master's thesis, Institute of Distance Learning, Kwame Nkrumah University of Science and Technology, Kumasi, Ghana.

Alpay, G., Bodur, M., Yilmaz, C. and Buyukbalc1, P. (2012). How does innovativeness yield superior firm performance? The role of marketing effectiveness. Innovation, Management, Policy and Practice, 14, pp. 107-128.

Anderson, B.S. and Eshima, Y. (2011). The influence of firm age and tangible resources on relationship between entrepreneurial orientation and firm growth among Japanese SMEs. Journal of Business Venturing, 28, pp. 413-429.

Bakar, L.J.A. and Ahmad, H. (2010). Assessing the relationship between firm resources and product innovation performance: A resource-based view. Business Process Management Journal, 16(3), pp. 420-435.

Barney, J.B. (1991). Firms resources and sustained competitive advantage. Journal of Management, 17, pp. 99-120.

Barney, J.B. (2001). Is the resource-based view a useful perspective for strategic management research? Yes. The Academic of Management Review, 26(1), pp. 4156.

Barney, J.B., Ketchen, D.J.Jr. and Wright, M. (2011). The future of resource-based theory: Revitalization or decline? Journal of Management, 37, pp. 1299-1315.

Boermans, M.A. and H. Roelfsema (2015). The effects of internationalization on innovation: Firm-level evidence for transition economies, Open Economies Review 26(2), pp. 333-350.

Bruderl, J., Preisendorfer, P., and Ziegler, R. (1992). Survival chances of newly founded business organisations. American Sociological Review, 57(2), pp. 227-242. 
Chiang, C., and Yan, H.D. (2011). Entrepreneurship, competitive advantages and the growth of the firm: The case of Taiwan's radio control model corporationthunder tiger. Journal of Small Business and Entrepreneurship, 24(4) pp. 513-530.

Chirico, F. and Salvato, C. (2008). Knowledge integration and dynamic organizational adaptation in family firms. Family Business Review, 21(2), pp. 169-181.

Choi, B.S. and Williams, C. (2012). The impact of innovation intensity, scope, and spillovers on sales growth in Chinese firms. Asian Pacific Journal of Management, 31, pp. 25-46.

Cohen, J, (1988). Statistical power analysis for behavioural sciences ( $2^{\text {nd }}$ ed.). Hillsdale, NJ: Lawrence Erlbaum Associates.

Creswell, W., and Plano Clark, V.L. (2007). Designing and conducting mixed methods research. Thousand Oaks, CA: Sage Publications.

Edelman, L.F., Brush, C.G. and Manolova, T.S. (2005). Co-alignment in the resourceperformance relationship: Strategy as a mediator. Journal of Business Venturing, 20(3), pp. 343-359.

Ellonen, R., Blomqvist, K. and Puumalainen, K. (2008). The role of trust in organizational innovativeness. European Journal of Innovation Management, 11(2), pp. 160-181.

Foss, N.J. (1998). The resource-based perspective: An assessment and diagnosis of problems. Scandinavian Journal of Management, 14, pp. 113-149.

Gadenne, D. and Sharma, B. (2009). An investigation of hard and soft quality management factors of Australian SMEs and their association with firm performance. International Journal of Quality and Reliability Management, 26(9), pp. 865-88o.

Ghana Statistical Service (2012a). 2010 Population and Housing Census, Summary Report of Final Results. Accra, Ghana: Ghana Statistical Service.

Ghana Statistical Service (2012b). Greater Accra Regional Analytical Report, 2010. Accra, Ghana: Ghana Statistical Service.

Global Entrepreneurship Monitor (2010). Global Report.

Grigoriou, K. and Rothaermel, F.T. (2014). Structural micro foundations of innovation: The role of relational stars. Journal of Management, 40, pp. 586-615.

Hayford, S. (2012). The development of small and medium-sized enterprises and their impact to the Ghanaian economy. Unpublished master's thesis, Institute of Distance Learning, Kwame Nkrumah University of Science and Technology, Kumasi, Ghana. 
Hoopes, D.G. Madsen, T.L. and Walker, G. (2003). Guest editors' introduction to the special issue: Why is there a resource-based view? Towards a theory of competitive heterogeneity. Strategic Management Journal, 24(10), pp. 559-902.

Iakovleva, T. (2004). Entrepreneurial performance in Russia. (University of Twente). Retrieved from http://www.utwente.n/nikos/esu/papers/iakovleva.pdf. Date Accessed: 26/02/2018.

Irava, W. and Moores, K. (2010). Resources supporting entrepreneurial orientation in multigenerational family firms. International Journal of Entrepreneurial Venturing, 2(3), pp. $222-245$.

Keklik, M. (2018). Schumpeter, Innovation and Growth. Long-Cycle Dynamics in the Post-WWII American Manufacturing Industries. London: Routledge.

Kraaijenbrink, J., Spender, J. and Groen, J. A. (2010). The resource-based view: A review and assessment of its critiques. Journal of Management, 10(36), pp. 349362.

Krejcie, R.V. and Morgan, D.W. (1970). Determining sample size for research activities. Educational and Psychological Measurement, 30, pp. 607-610. Retrieved from http://people.usd.edu/ mbaron/edad810/Krejcie.pdf.

Leech, N., Barrett, K.C. and Morgan, G. (2005). SPSS for intermediate statistics: Use and interpretation ( $6^{\text {th }}$ ed.). Mahwah, NJ: Lawrence Erlbaum Associates.

Liu, Y. and Phillips, J.S. (2011). Examining the antecedents of knowledge sharing in facilitating team innovativeness from a multilevel perspective. International Journal of Information Management, 31(2), pp. 44-52.

Marcati, A., Guido, G. and Peluso, A.M. (2008). The role of SME entrepreneurs' innovativeness and personality in the adoption of innovations. Research Policy, 37, pp. 1579-1590.

Mata, F., Fuerst, W. and Barney, J. (1995). Information technology and sustained competitive advantage: A resource-based analysis. Management Information Systems Quarterly, 19 (4), pp. 487-498.

Mensah, S. (2004). A review of SME financing schemes in Ghana. Paper presented at (UNIDO Regional Workshop of Financing Small and Medium Scale Enterprises, Accra, Ghana, 15-16 March, 2004).

Ngugi, J.K., McOrege, M.O. and Muiru, J.M. (2013). The influence of innovativeness on the growth of SMEs in Kenya. International Journal of Business and Social Research, 3, pp. 25-31.

O’Regan, N., and Ghobadian, A. (2004). The importance of capabilities for strategic direction and performance. Management Decision, 42(2), pp. 292-312. 
Organization for Economic Co-operation and Development - OECD, (2005). Oslo Manual: Guidelines for collecting and interpreting innovation data ( $3^{\text {rd }}$ ed.). Paris: OECD Publications.

Pallant, J. (2010). SPSS survival manual: A step-by-step guide to data analysis using SPSS for windows ( $4^{\text {th }}$ ed.) Maidenhead: Open University Press.

Peteraf, M. (1993). The cornerstones of competitive advantage: A resource-based view. Strategic Management Journal, 14(3), pp. 179-191.

Porter, M.E. (1991). Towards a dynamic theory of strategy. Strategic Management Journal, 12, pp. 95-117.

Price, D., Stoica, M. and Boncella, R. (2013). The relationship between innovation, knowledge and performance in family and non-family firms: An analysis of SMEs. Journal of Innovation and Entrepreneurship, 2, pp. 157-187.

Rasmussen, C.C. (2014). Intangible resources as drivers of high growth. International Journal of Innovation Management, 18(4), pp. 1-20.

Robson, P.J.A., Haugh, H.M. and Obeng, B. A. (2009). Entrepreneurship and innovation in Ghana: Enterprising Africa. Small Business Economics, 32(3), pp. 331-350.

Robson, P.J.A. and Obeng, B.A. (2008). Barriers to growth in Ghana. Small Business Economics, 30(4), 385-403.

Rosenbusch, N., Brinckmann, J. and Bausch, A. (2011). Is innovation always beneficial? A meta-analysis of the relationship between innovation and performance in SMEs. Journal of Business Venturing, 26(4), pp. 441-457.

Rosli, M.M. and Sidek, S. (2013). Innovation and firm performance: Evidence from Malaysian small and medium enterprises. Paper presented at the $\left(20^{\text {th }}\right.$ International Business Information Management Conference, Kuala Lumpur, Malaysia, 25-26 ${ }^{\text {th }}$ March 2013).

Rugman, A.M. and Verbeke, A. (2002). Edith Penrose's contribution to the resourcebased view of strategic management. Strategic Management Journal, 23(8), pp. 769-780.

Salavou, H., and Avlonitis, G. (2008). Product innovativeness and performance: A focus on SMEs. Management Decision, 46(7), pp. 969-985.

Saunders, M., Lewis, P. and Thornhill, A. (2012). Research methods for business students ( $6^{\text {th }}$ ed.). Harlow, England: Pearson Education.

Scherer, F. M. (1986). Innovation and Growth: Schumpeterian Perspectives. MIT Press Books, The MIT Press, edition 1, volume 1, number 0262691027, January. 
Schumpeter, J.A. (1934). The theory of economic development: An inquiry into profits, capital, credit, interest and business cycle. Cambridge, MA: Harvard University Press.

Sekaran, U. and Bougie, R. (2010). Research methods for business: A skill building approach ( $5^{\text {th }}$ ed.). New Jersey, NJ: John Wiley and Sons.

Sonja, R. and Ljiljana, B. (2012). Overcoming failure: Abandonments and delays of innovation projects in SMEs. Industry and Innovation, 19(8), pp. 649-669.

Storey, V.M., Boso, N. and Kadogan, J.W. (2015). The form of relationship between firm-level product innovativeness and new product performance in developed and emerging markets. Journal of Product Innovation Management, 32(1), pp. 45-64.

Tabachnick, B. G. and Fidell, L. S. (2007). Using multivariate statistics. (2nd ed.). Boston: Pearson/Allyn and Bacon.

Tangen, S. (2004) Performance measurement: from philosophy to practice. International Journal of Productivity and Performance Management, 53(8), pp. 726-737.

Teece, D.J. (2007). Explicating dynamic capabilities: The nature and micro foundations of sustainable enterprise performance. Strategic Management Journal, 28, pp. 1319-1350.

Terrell, S.R. (2012). Mixed methods research methodologies. The Qualitative Report, 17, pp. 254-28o.

Vicente, M., Abrantes J.L., Seabra, C. and Teixeira, M.S. (2015). Innovation, dynamic capabilities and performance in export markets. The Macro-theme Review, 4(6), pp. 136-158.

Wiklund, J., Patzelt, H., and Shepherd, D.A. (2007). Building an integrative model of small business growth. Small Business Economics, 32(4), pp. 351-374.

Williamson, O.E. (1999). Strategic research: Governance and competence Perspectives. Strategic Management Journal, 20, 1087-1108.

Woldie, A., Leighton, P. and Adesua, A. (2008). Factors influencing small and mediumsized enterprises (SMEs): An exploratory study of owner/manager and firm characteristics. International Journal of Banks and Banking Systems, 3(3), pp. 5-13. 
Yan, S. (2010). Competitive strategy and business environment: The case of China. Asian Social Science, 6(11), pp. 45-59.

Zahra, S. and Covin, J. (1995). Contextual influence on the corporate entrepreneurshipperformance relationship: A longitudinal analysis. Journal of Business Venturing, 10, pp. 43-58. 